\title{
Agriculture as an Index of Socio-Economic Development of Delta State of Nigeria
}

\author{
Vincent Nduka Ojeh ${ }^{1, *}$, Thaddeus Origho ${ }^{2}$, Philip Henah John $^{3}$ \\ ${ }^{1}$ Department of Geography \& Regional Planning, Delta State University, Abraka, Nigeria \\ ${ }^{2}$ Department of Geography, College of Education, Warri, Nigeria \\ ${ }^{3}$ Department of Geography \& Regional Planning, University of Benin, Benin City, Nigeria
}

\begin{abstract}
The paper examined Agriculture as an index of socio-economic development of DeltaState of Nigeria. Secondary data from the Delta State Household Surveyformed the core of the data used for the study. The stratified random sampling technique was used in administering 2024 questionnaires to respondents in DeltaState. Simple percentages, bar graphs and pie-chart were used for the data analysis. The results of the study showed that agricultural practices in Delta State is gender sensitive with more males than females participating in agricultural production. In addition, fish farming and livestock production are on the decline, while crop farming is the major interest of the farmers. The swampy areas of DeltaStateare grossly underutilized with respect to agricultural productivity, while irrigation farming should be encouraged. The government of DeltaState should also assist farmers by providing them with credit facilities especially in the rural area. Solutions to the identified problems were proffered.
\end{abstract}

Keywords Agriculture, Development, Delta State, Nigeria

\section{Introduction}

World agriculture, in fact comprises of two distinct types of farming (a) the highly efficient agriculture of the developed countries; where substantial productive capacity and high output per workers permit a very small number of farmers to feed entire nations; and (b) the inefficient and low productivity agriculture of developing countries where in many instances the agricultural sector can barely sustain the farm population let alone, the burgeoning urban population, even at a minimum level of subsistence[1]

Agriculture is the backbone of Africa's economy. About $70 \%$ of Africans and roughly $80 \%$ of the continent's poor live in the rural areas and depends mainly on agriculture for their livelihood. The sector accounts for about $20 \%$ of the total merchandise exports[2] Agriculture is the main source of income for $90 \%$ of the African population. About $70 \%$ of the African population, Nigeria inclusive, living on less than $1 \$$ (One dollar) a day are located in rural areas[3] establishing poverty as a rural phenomenon in the region. The study of Inoni[4] revealed that livestock income from small-holder farmers exert a positive and statistically significant $(p<0.01)$ effect on improved nutrition, household food security and consequently, rural poverty alleviation. This will help not only to reduce hunger but necessary for

* Corresponding author:

vinceojeh@yahoo.com(Vincent Nduka Ojeh)

Published online at http://journal.sapub.org/env

Copyright (C) 2012 Scientific \& Academic Publishing. All Rights Reserved accelerating development and poverty reduction.

The contribution of agriculture to economic development lies in providing more food to the rapidly expanding population; increasing the demand for industrial products and thus necessitating the expansion of the secondary and tertiary sector; providing additional foreign exchange earnings for the import of capital goods for development through increased agricultural exports, increasing rural incomes to be mobilized by the state; providing productive employment and improving the welfare of the rural people[5]. Ozor and Nwankwo[6], reiterated that self-sustained rural community development is vital to the economic and social progress of any developing nation like Nigeria, and that unless the ways and means of massively accelerating development in the rural areas where over $80 \%$ of Nigeria's population reside[7] our national goal of self-sufficiency and control over resources may continue to elude us.

In less developed countries, food production dominates the agricultural sector while output expands with increased productivity it increases the income of the farmers. However, the increase in the growth rate of population due to a rapid decline in the mortality rates and slow reduction in the fertility rates tends to raise further the demand for food beside the demand for food increases with expansion of population in towns and industrial areas. Thus, the increase in farm output should be at higher rate than the increase of food demand. In a situation where the increased production of agricultural commodities lags behind growth in demand, there will be a substantial rise in food prices. To offset domestic shortage and prevent rise in prices, food may be im- 
ported from abroad but it can be at the cost of capital goods needed for development. The state may also introduce price controls, rationing and compulsory food collection. All these emphasise the importance of increase in food production in less developed countries[5].Explaining the roles of Information and Communication Technology in actualizing increase food production, Achugbue and Anie[8] opined that it is sad to know that most African countries have not devoted adequate attention to providing their citizens with access to information especially in rural areas. Unomah[9] posits that rural people need information on how to apply fertilizers in the farm, preservation of harvested crops, and marketing of the farm produce. Information is essential for facilitating agricultural and rural development and bringing about social and economic change.

In addition, a rise in rural purchasing power as a result of the increased agricultural surplus is a great stimulus to industrial development. The market for manufactured goods is very small in an underdeveloped country like Nigeria. However, increased rural purchasing power caused by expansion of agricultural output and productivity will tend to raise the demand for manufactured goods and extend the size of the market. This will lead to the expansion of the industrial sector.

Furthermore, underdeveloped countries such as Nigeria, mostly specialize in the production of a few agricultural goods for export, their exports increase and result in larger foreign exchange earnings. This agricultural surplus leads to capital formation when capital goods are imported with this foreign exchange.

Again, an underdeveloped country needs large amount of capital to finance the creation and expansion of the infrastructure and for the development of basic and heavy industry. According to Johnson and Mellor[10] "An increase in agricultural productivity implies some combination of reduced agricultural prices or increased farm receipts."

Agriculture also expands and diversifies employment opportunities in rural areas. As agricultural productivity and farm income increase, non-farm rural employment expands and diversifies. Thus, landless and marginal farmers are primarily engaged in non-agricultural pursuits which include the manufacture of textile, furniture tools, handicrafts, leather and metal working etc. All activities satisfy local demand. In addition, increase in rural incomes as a result of the agricultural surplus tends to improve rural welfare. Peasants start consuming more food especially of a higher nutritional value in the form of superior quality cereals, eggs, milk, fruits, etc. They build better houses fitted with modern amenities. Thus, increased agricultural surplus has the effect of raising the standard of living of the mass of the rural people.

Funding of agriculture in the rural areas where the bulk of the farmers live have also brought a lacuna in accelerating socio-economic development via agriculture. For instance, in spite of the importance of loan in agricultural production, its acquisition is fraught with a number of problems. The small scale farmers are forced to source for capital from relations, moneylenders and contribution clubs[11]. All of theseareknowntobeineffectiveinprovidingcapitalforsubstanti alincreaseinagriculturalproduction.In his view[12], asserted that Credit availability to agriculture is justified when farmers are faced with low savings capacity, poorly developed rural financial markets and limited availability of appropriate farm technologies whose adoption is constrained by shortage of funds. The study of[13] revealed that farm income, profit, education, and interest amount determined demand for credit by farmers whereas liquidity, experience in lending and interest amount determined supply.

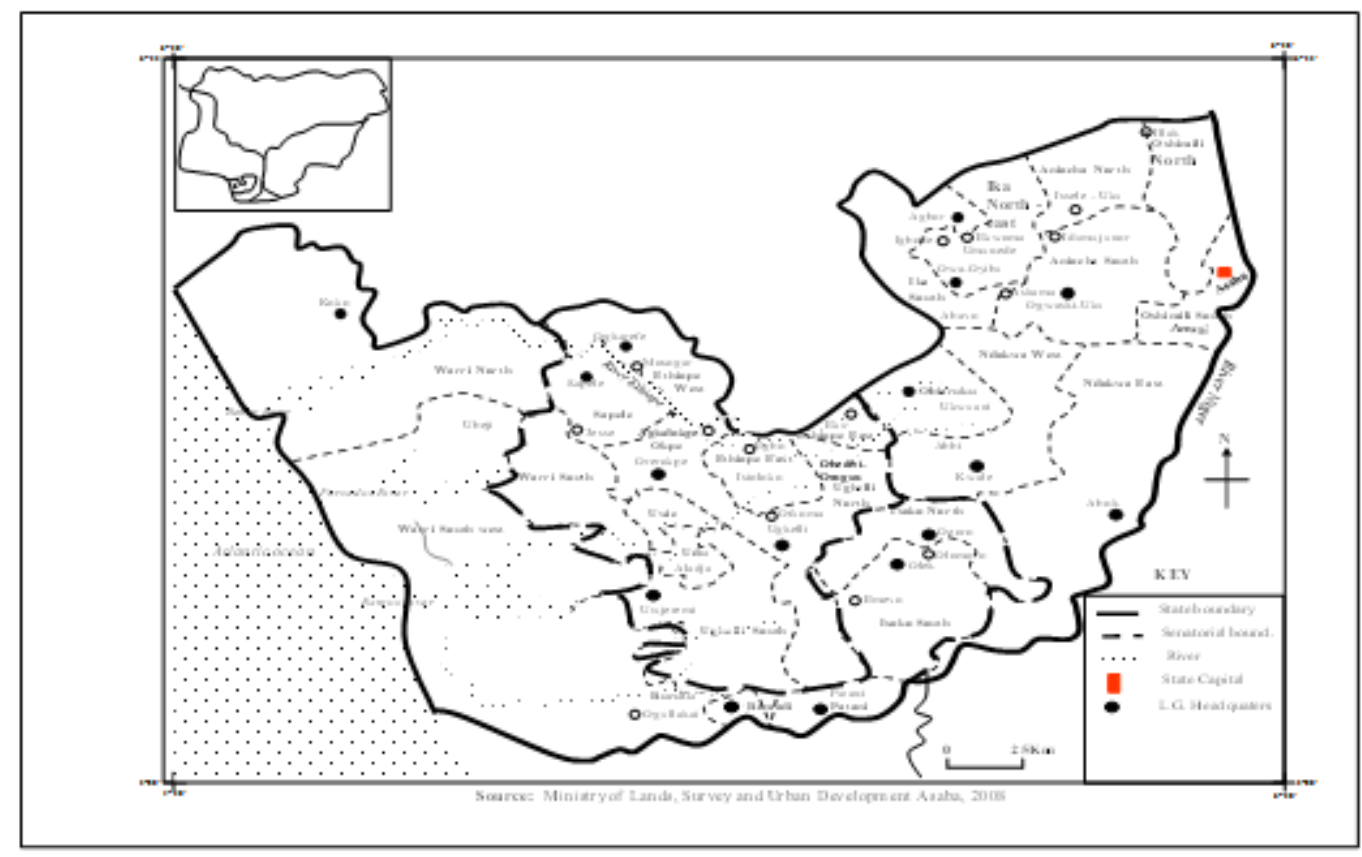

Figure 1. Delta State: Location of Study Area 
Deriving from the above, the authors examine agriculture as an index of socio-economic development in DeltaState of Nigeria.

\section{The Study Area}

Delta State is located between latitude $5^{\circ} 00$ North and latitude $6^{\circ} 30^{\prime}$ North and longitude $5^{\circ}$ East and longitude $6^{\circ} 45^{\prime}$ East. DeltaState is located in the southern part of Nigeria. The southern part of the State is essentially riverine with numerous rivers and creeks, marshy terrain and mangrove swamps. The topography barely lies above the sea level, resulting in the incidences of floods in the rainy season. However, the northern part of the state is a tropical rain forest belt.

The state is bounded in the north by EdoState, OndoState to the North-West, Anambra to the East, Rivers to the South-East and to the South by the Bight of Benin which covers approximately 160 kilometres of the state coastline. It has 25 Local Government Areas (Fig.1) below. The state has its capital at Asaba. It has a population of 4,098,391 (14).

\section{Methodology}

The data was generated mainly from secondary sources. The Delta State Household survey[15] provided most of the data used for the paper. Other sources of data included journals, textbooks, reports, etc to mention but a few.

In addition, the data collected focused on the area of man power, type of farming, land tenure, rent, patterns, and credit patterns. The indicators in the agricultural sectors included.
Engagement in agriculture; type of farming activity; farm holding locations; type of land tenure; rent etc. A total of 2024 questionnaires were distributed to respondent using the stratified random sampling technique. However, not all were returned. This is reflected in the totals of the tables of 1958 and 1959. The data was further analysed with simple percentage and was depicted with bar graphs and pie charts.

\section{Discussion}

The spatial distribution of persons engaged either as full-time or part-time farmers in the various local government areas that make up DeltaState are shown in table 1 below by percentages.

It was observed that $36.8 \%$ of the males and $29.5 \%$ of the females in DeltaState were engaged in full-time agriculture. However, on part-time basis $19.86 \%$ of men and $13.8 \%$ of the women were involved in agriculture.

Specifically, the percentage of males involved in full-time farming in the various local government areas include: Aniocha-North (40.7\%), Aniocha South (47.3\%), Burutu (43.7\%), Patani (49.1\%); Sapele (48.9\%); Udu (41.4\%); Ughelli North (44\%); However, female participation in full-time agriculture in the local government areas of Delta State were represented as follows: Aniocha (33.1\%); Bomadi (47.6\%) Ethiope East (47.5\%); Ethiope West (53.8\%) Okpe (66.7\%); Oshimili (35.9\%); Patani (47.3\%); and Udu $(35.7 \%)$. There were no responses from Ukwuani local government for either full-time or part-time farmers.

Table 1. Spatial Distribution of Persons Engaged in Agriculture within Local Government Areas of Delta State by Percentages

\begin{tabular}{|c|c|c|c|c|}
\hline \multirow{3}{*}{ LGALocal Government Area } & \multicolumn{4}{|c|}{ NO OF PERSONS ENGAGED (\%) } \\
\hline & \multicolumn{2}{|c|}{ FULL TIME } & \multicolumn{2}{|c|}{ PART Time } \\
\hline & Male & Female & Male & Female \\
\hline Aniocha North & 40.7 & 33.1 & 16.1 & 10.2 \\
\hline Aniocha South & 47.3 & 18.2 & 18.18 & 10.4 \\
\hline Bomadi & 38.1 & 47.6 & 9.524 & 4.76 \\
\hline Burutu & 43.7 & 29.8 & 15.32 & 11.1 \\
\hline Ethiope East & 5.0 & 47.5 & na & 2.5 \\
\hline Ethiope West & 35.2 & 53.8 & 10.99 & na \\
\hline Ika North East & 19.4 & 14.9 & 36.78 & 28.9 \\
\hline Ika South & 33.3 & 16.7 & 16.67 & 33.3 \\
\hline Isoko North & 19.1 & 21.7 & 38.3 & 21.3 \\
\hline Isoko South & 2.0 & 2.0 & 5.0 & 10 \\
\hline Ndokwa East & na & na & na & na \\
\hline Ndokwa West & 2.0 & 8.0 & na & na \\
\hline Okpe & 33.3 & 66.7 & na & na \\
\hline Oshimili North & 32.6 & 35.9 & 19.57 & 12 \\
\hline Oshimili South & na & 1.00 & na & na \\
\hline Patani & 49.1 & 47.3 & na & 3.64 \\
\hline Sapele & 48.9 & 28.9 & 6.667 & 15.6 \\
\hline Udu & 41.4 & 35.7 & 14.01 & 8.92 \\
\hline Ughelli North & 44 & 17.4 & 26.09 & 12.5 \\
\hline Ughelli South & 32.6 & 32 & 18.49 & 10.9 \\
\hline Ukwuani & na & na & na & na \\
\hline Uvwie & 1.00 & na & na & na \\
\hline Warri North & 5.0 & na & na & na \\
\hline Warri South & 83.0 & 1.0 & 6.667 & na \\
\hline Warri South-West & 5.5 & na & 35 & 10 \\
\hline State & 36.8 & 29.5 & 19.86 & 13.8 \\
\hline
\end{tabular}

Source: Delta State Household Survey[15]

*naNot available 
Table 2. Distribution of Types of Farm ownership within Local Government Areas by Numbers and Percentages

\begin{tabular}{|c|c|c|c|c|}
\hline \multirow{2}{*}{ LGA } & \multicolumn{4}{|c|}{ TYPES OF FARM OWNERSHIP } \\
\hline & As an individual & Jointly as individuals with households & Jointly with members of households & Totals \\
\hline Aniocha North & $37(52.1 \% \%$ & $28(39.4 \%)$ & $6(8.5 \%)$ & 71 \\
\hline Aniocha South & $69(90.8 \%)$ & $7(9.2 \%)$ & - & 76 \\
\hline Bomadi & $35(100 \%)$ & - & - & 35 \\
\hline Burutu & $20(87.0 \%)$ & $2(8.7 \%)$ & $1(4.3 \%)$ & 23 \\
\hline Ethiope East & $100(90.0 \%)$ & $10(71.2 \%)$ & - & 110 \\
\hline Ethiope West & $47(26.6 \%)$ & $126(71.2 \%)$ & $4(2.3 \%)$ & 177 \\
\hline Ika North East & $141(69.1 \%)$ & $63(30.9 \%)$ & - & 204 \\
\hline Ika South & $74(93.7 \%)$ & $3(3.8 \%)$ & $2(25 \%)$ & 79 \\
\hline Isoko North & $63(98.4 \%)$ & - & $1(1.6 \%)$ & 64 \\
\hline Isoko South & $134(88.7 \%)$ & $11(7.3 \%)$ & $6(4.0 \%)$ & 151 \\
\hline Ndokwa East & $98(56.6 \%)$ & $66(38.2 \%)$ & $9(5.2 \%)$ & 173 \\
\hline Ndokwa West & $182(93.3 \%)$ & $7(3.6 \%)$ & $6(3.1 \%)$ & 195 \\
\hline Okpe & $32(84.2 \%)$ & $5(13.8 \%)$ & $1(2.6 \%)$ & 38 \\
\hline Oshimili North & $41(75.9 \%)$ & $13(24.1 \%)$ & - & 54 \\
\hline Oshimili South & $3(25 \%)$ & $3(25.0 \%)$ & $6(50 \%)$ & 12 \\
\hline Patani & $39(100 \%)$ & $39(97.5 \%)$ & $1(2.5 \%)$ & 40 \\
\hline Sapele & $85(96.6 \%)$ & $1(1.1 \%)$ & $2(2.3 \%)$ & 88 \\
\hline Udu & $38(100 \%)$ & - & - & 38 \\
\hline Ughelli North & $8(100 \%)$ & - & - & 8 \\
\hline Ughelli South & $161(79.3 \%)$ & $37(31.4 \%)$ & $1(0.5 \%)$ & 203 \\
\hline Ukwani & $78(66.1 \%)$ & $37(31.4 \%)$ & $3(2.5 \%)$ & 118 \\
\hline Uvwie & $1(100 \%)$ & - & - & 1 \\
\hline Warri North & $1(100 \%)$ & - & - & 1 \\
\hline Warri South & - & - & - & - \\
\hline Warri South-West & - & - & - & - \\
\hline Total & $1487(75.9 \%)$ & $424(21.6 \%)$ & $48(2.5 \%)$ & 1959 \\
\hline
\end{tabular}

Source: Delta State Household Survey[15]

Table 3. Spatial distribution of farmers by type of agricultural production activities and LGA (by numbers and percentages)

\begin{tabular}{|c|c|c|c|c|}
\hline \multirow{2}{*}{ LGA } & \multicolumn{4}{|c|}{ TYPES OF AGRICULTURAL PRODUCTION } \\
\hline & Crop farming & Livestock farming & Fish farming & Total \\
\hline Aniocha North & $71(100 \%)$ & - & - & 71 \\
\hline Aniocha South & $75(98.7 \%)$ & - & 1 & 76 \\
\hline Bomadi & $35(100 \%)$ & - & - & 35 \\
\hline Burutu & $8(34.8 \%)$ & $2(8.7 \%)$ & $13(56.5 \%)$ & 23 \\
\hline Ethiope East & $110(100 \%)$ & - & - & 110 \\
\hline Ethiope West & $117(100 \%)$ & - & - & 117 \\
\hline Ika North East & $200(97.1 \%)$ & $6(2.9 \%)$ & - & 206 \\
\hline Ika South & $79(100 \%)$ & - & - & 79 \\
\hline Isoko North & $64(100 \%)$ & - & - & 64 \\
\hline Isoko South & $157(100 \%)$ & - & - & 151 \\
\hline Ndokwa East & $170(98.3 \%)$ & $2(1.2 \%)$ & - & 173 \\
\hline Ndokwa West & $191(97.9 \%)$ & $2(1.0 \%)$ & $1(0.6 \%)$ & 195 \\
\hline Okpe & $33(100 \%)$ & - & $2(1.0 \%)$ & 33 \\
\hline Oshimili North & $53(98.1 \%)$ & $1(1.9 \%)$ & - & 54 \\
\hline Oshimili South & $14(100 \%)$ & - & - & 14 \\
\hline Patani & $40(100 \%)$ & - & - & 40 \\
\hline Sapele & $86(97.7 \%)$ & $1(1.1 \%)$ & $1(1.1 \%)$ & 88 \\
\hline Udu & $38(100 \%)$ & - & - & 38 \\
\hline Ughelli North & $8(100 \%)$ & - & - & 8 \\
\hline Ughelli South & $189(93.1 \%)$ & $12(5.9 \%)$ & $2(1.0 \%)$ & 203 \\
\hline Ukwani & $105(98.0 \%)$ & $13(11.0 \%)$ & - & 118 \\
\hline Uvwie & $1(100 \%)$ & - & - & 1 \\
\hline Warri North & $1(100 \%)$ & - & - & 1 \\
\hline Warri South & - & - & - & - \\
\hline Warri South-West & - & - & - & - \\
\hline Total & $1899(97 \%)$ & $39(2.0 \%)$ & $20(1.0 \%)$ & 1958 \\
\hline
\end{tabular}

Source: Delta State Household Survey[15] 
In addition, the type of farming ownership by local government areas is presented in table 2 by numbers and percentages.

It was observed that majority of farms are individually owned represented by $1487(75.9 \%)$, while jointly owned by individuals with members of household was 424(21.6\%). Joint ownership with members of other household was the least with 48 represented by $2.5 \%$.

Again the distribution of farmers by type of agricultural production activities and local government areas were also examined in table 3 . These include crop farming, livestock farming and fish farming to mention a few.

The data in table 3 revealed that crop farming was the major type of farming practiced in the various Local government areas of Delta State. This was represented by $97 \%$ of the overall farming activities. In addition, in Burutu Local Government Area, more of the farmers were into fish farming represented by $56.5 \%$, while farming accounted for $34.8 \%$ and livestock farmers $8.7 \%$ respectively. However, fish farming in the state accounted for only $1.0 \%$ of farming activities. Thus, more emphasis is now shifting to crop farming while livestock and fishing are now declining in emphasis.

Table 4. Percentage Distribution of Land by Types of Land and Local Government Areas

\begin{tabular}{|c|c|c|c|}
\hline \multirow{2}{*}{ LGA } & \multicolumn{3}{|c|}{ TYPES OF LAND } \\
\cline { 2 - 4 } & $\begin{array}{c}\text { Upland Rain } \\
\text { fed }\end{array}$ & $\begin{array}{c}\text { Lowland } \\
\text { swamp }\end{array}$ & Irrigated \\
\hline Aniocha North & 100 & - & - \\
\hline Aniocha South & 88.2 & 11.8 & - \\
\hline Bomadi & 100 & - & - \\
\hline Burutu & - & 87.5 & 12.5 \\
\hline Ethiope East & 100 & - & - \\
\hline Ethiope West & 100 & - & - \\
\hline Ika North East & 98 & 2 & - \\
\hline Ika South & 100 & - & - \\
\hline Isoko North & 95.2 & 4.8 & - \\
\hline Isoko South & 20.7 & 79.3 & - \\
\hline Ndokwa East & 76.7 & 23.3 & - \\
\hline Ndokwa West & 75.1 & 24.9 & - \\
\hline Okpe & 100 & - & - \\
\hline Oshimili North & 98.1 & 1.9 & - \\
\hline Oshimili South & 100 & - & - \\
\hline Patani & - & 100 & - \\
\hline Sapele & 98.9 & 1.1 & - \\
\hline Udu & 100 & - & - \\
\hline Ughelli North & 100 & - & - \\
\hline Ughelli South & 19.7 & 80.3 & - \\
\hline Ukwuani & 100 & - & - \\
\hline Uvwie & 100 & - & - \\
\hline Warri North & 100 & - & - \\
\hline Warri South & - & - & - \\
\hline Warri & - & - & - \\
\hline South-West & 77.1 & 22.8 & 0.1 \\
\hline State & & & \\
\hline Sorce: Deta Ste & & - \\
\hline
\end{tabular}

Source: Delta State Household Survey[15]
Furthermore, the authors also examined the percentage distribution of land by type of land and Local Government Areas as shown in table 4.

The data in table 4 shows that most of the farms are upland (rain fed) accounting for $77.1 \%$ and lowland (Swampy) represented by $22.8 \%$, while irrigated type of farming $(0.1 \%)$ was only found in Burutu. However, lowland (Swampy) dominated type of land in Isoko South and Ughelli South accounting for $79.3 \%$ and $80.3 \%$ respectively. Since the majority of the farms are upland (rain fed), farmers have to rely on rainfall to water their crops which to a large extent can affect the yearly harvest. Furthermore, for the farmers in the various local government areas to be able to meet their farming needs, they had to depend on credit facilities as stated in table 5 .

It was observed from table 5, that $13.6 \%$ of the farmers interviewed took credit facility while $86.4 \%$ did not. Ndokwa west with $36.6 \%$ and Ika North East $48.9 \%$ have the highest number of their farmers that took credit facility. However, if only $13.6 \%$ accounted for farmers that took credit facility, it could be said that many of the farmers did not want credit facility because of fear of re-payment in case of poor crop yield. It could also be that efforts to obtain loans in the past met with the brick wall of bureaucratic delay and as such they felt government credit facilities are not accessible.

Table 5. Percentage Distribution of Credit Facilities by Local Government Areas

\begin{tabular}{|c|c|c|}
\hline \multirow{2}{*}{ LGA } & \multicolumn{2}{|c|}{ CREDIT FACILITY } \\
\hline & YES & No \\
\hline Aniocha North & 1.5 & 985 \\
\hline Aniocha South & 15.8 & 84.2 \\
\hline Bomadi & 32.3 & 67.6 \\
\hline Burutu & 80 & 20 \\
\hline Ethiope East & - & 100 \\
\hline Ethiope West & 4.2 & 5.8 \\
\hline Ika North East & 48.9 & 51.2 \\
\hline Ika South & 21.8 & 78.2 \\
\hline Isoko North & 19 & 81 \\
\hline Isoko South & 7.3 & 92.7 \\
\hline Ndokwa East & 22.4 & 77.6 \\
\hline Ndokwa West & 36.6 & 63.4 \\
\hline Okpe & - & 100 \\
\hline Oshimili North & - & 100 \\
\hline Oshimili South & 7.1 & 42.9 \\
\hline Patani & - & 100 \\
\hline Sapele & 3.4 & 96.6 \\
\hline Udu & - & 100 \\
\hline Ughelli North & 25.0 & 75.0 \\
\hline Ughelli South & - & 100 \\
\hline Ukwani & 7.6 & 92.4 \\
\hline Uvwie & - & 100 \\
\hline Warri North & 100 & - \\
\hline Warri South & - & - \\
\hline Warri South-West & - & - \\
\hline State & 13.6 & 86.4 \\
\hline
\end{tabular}

Source: Delta State Household Survey[15] 
Table 6. Percentage Distribution of Agricultural Production Activities by source of fund and Local Government Area

\begin{tabular}{|c|c|c|c|c|c|c|c|}
\hline LGA & $\begin{array}{l}\text { Friends/ } \\
\text { Relatives }\end{array}$ & $\begin{array}{c}\text { Micro-finance } \\
\text { Bank } \\
\end{array}$ & $\begin{array}{c}\text { Commercial } \\
\text { Bank } \\
\end{array}$ & $\begin{array}{c}\text { Co-operate } \\
\text { society }\end{array}$ & $\begin{array}{c}\text { Local money } \\
\text { Lender }\end{array}$ & $\begin{array}{c}\text { Traditional contribution } \\
\text { (Esusu) }\end{array}$ & $\begin{array}{c}\text { Other } \\
\text { sources }\end{array}$ \\
\hline Aniocha North & - & - & - & - & - & - & - \\
\hline Aniocha South & 16.7 & - & - & 8.3 & 16.7 & 58.3 & \\
\hline Bomadi & 18.2 & - & - & 27.3 & - & 36.4 & 18.2 \\
\hline Burutu & 25 & & & & 5.0 & 25 & - \\
\hline Ethiope East & - & - & - & - & - & - & - \\
\hline Ethiope West & 14.3 & - & - & - & - & 85.7 & - \\
\hline Ika North East & 3.8 & 3.8 & - & 3.8 & - & 77.4 & 11.3 \\
\hline Ika South & 29.4 & - & - & 11.8 & - & 52.9 & 5.9 \\
\hline Isoko North & 33.3 & - & - & 8.3 & - & 50 & 8.3 \\
\hline Isoko South & 10.0 & - & - & - & - & 80.0 & 10 \\
\hline Ndokwa East & 20.8 & - & - & - & - & 12.5 & 66.7 \\
\hline Ndokwa West & 33.7 & 4.9 & - & 3.3 & 16.4 & 33.7 & - \\
\hline Okpe & - & - & 100 & - & - & - & - \\
\hline Oshimili North & - & 100 & - & - & - & - & - \\
\hline Oshimili South & - & - & - & - & - & 100 & - \\
\hline Patani & 57.5 & - & - & - & - & 22.5 & 20.0 \\
\hline Sapele & 51.1 & 1.1 & - & - & - & 28.4 & 19.3 \\
\hline Udu & 81.6 & - & - & - & - & 5.3 & 13.2 \\
\hline Ughelli North & - & - & - & 50 & - & 50 & - \\
\hline Ughelli South & - & 100 & - & - & - & - & - \\
\hline Ukwuani & 1.7 & 5.1 & - & - & 0.8 & 63.6 & 28.8 \\
\hline Uvwie & - & - & - & - & - & - & - \\
\hline Warri North & 100 & - & - & - & - & - & - \\
\hline Warri South & - & - & - & - & - & - & - \\
\hline Warri South-West & - & - & - & - & - & - & - \\
\hline State & 19.6 & 35.4 & 0.1 & 1.6 & 2.0 & 29.3 & 12.1 \\
\hline
\end{tabular}

Source: Delta State Household Survey[15]

Thus, it becomes expedient that the private sector and government should collaborate to sensitize farmers on the various credit facilities that are available and how to obtain them through organized seminars, workshops and radio/television jingles.

Finally, the authors examined the distribution of agricultural production activities by source of fund and local government areas as shown in table 6 .

It was observed from table 6 that micro-finance bank had the highest percent $(35.4 \%)$ as source of funds for agricultural production activities, followed by traditional contribution (Esusu) 29.3\% and friend and relatives (19.6\%). Commercial bank accounted for only $0.1 \%$ which is the least source of fund. In addition, in Sapele (51.1\%) and Udu $(81.6 \%)$, friends/relatives were the most viable source of fund. Also in Oshimili North (100\%) and Ughelli North $(100 \%)$ micro-finance bank was the major source of fund. There is a recent improvement experiences in funding of agriculture across the country since the beginning of 2012 . The Federal Government of Nigeria has been emphasizing turning agriculture to a business and as such State Governments are releasing funds to farmers who are able to form cooperatives. This is further buttressed on the $16^{\text {th }}$ of April, 2012 when the Delta State Government disburse done billion naira $(\mathrm{N} 1,000,000,000)$ agricultural loan to 934 farmers' cooperatives in the state under the Commercial Agriculture Fund as directed by the Federal Government.N21.7 million out of the N1 billion had been set aside as insurance[16]

\section{Policy Implications}

Based on the data analysis above the following policy implications have been identified for the Delta Sate Government's implementation:

1) Farming in DeltaState is gender-sensitive in favour of male participation than females. Therefore, government should also encourage more women to participate in farming activities.

2) Government should encourage fish farming especially in the riverine areas of the State. Livestock farming should also be encouraged by the state government in a greater measure.

3) The swampy areas of Delta State should be utilized more for agriculture especially the cultivation of rice by the government while irrigation agriculture should be encouraged.

4) The government of Delta State should provide more credit facilities to farmers especially in the rural areas to increase their agricultural productivity to ensure adequate food security in the state.

\section{Conclusions}

Traditionally, the role of agriculture in economic development has been viewed as passive and supportive. As a result, agriculture's primary role was to provide sufficient low-priced food and manpower to the expanding industrial 
economy, which was thought to be dynamic.

Today, development economist have come to realize that far from playing a passive, supportive role in the process of economic development, the agricultural sector in particular and the rural economy in general, must play an indispensible part in an overall strategy of economic progress especially for low-income developing countries like Nigeria[1]. The situation in Delta State of Nigeria with respect to agricultural production vis-a-vis socio-economic development is not an exception.

\section{REFERENCES}

[1] Todaro, M.P and Smith, S.C (2006), Empowering farmers in SSA: Best practise. Findings, No. 33. February

[2] Comprehensive Africa Agricultural Developmen t(CAAD) (2003)

[3] World Bank (1995), Empowering farmers in SSA: Best Practices. Findings, No. 33. February

[4] Inoni, O.E. (2010). Effects of Small-holder Livestock Production in Reducing Rural Poverty in the Central Agricultural Zone of Delta State, Nigeria, Libyan Agriculture Research Center Journal International 1(3): 171-176.

[5] Jhingan, M.L. (2007), The Economics of Development and Planning. $39^{\text {th }}$ Revised and Enlarged Edition.

[6] Ozor, N and Nwankwo, N. (2008). The Role of Local Leaders in Community Development Programmes in Ideato Local Government Area of Imo State: Implication for Extension Policy, Journal of Agricultural Extension, 12 (2): 63-75.
[7] Guardian Newspaper Limited (2008) Health minister Prof. Grange and deputy, Aduku, resign over N300M scam charges. Wednesday March 26.

[8] Achugbue, E.I and Anie, S.O. (2011). ICTs and Information Needsof Rural Female Farmers inDelta State, Nigeria, $L i$ brary Philosophy and Practice, ISSN 1522-0222.

[9] Unomah, A (1998). Rural Librarianship: Panacea for Grassroots Development. APaper presented at Annual General Conference of the Nigerian LibraryAssociation, Delta State Chapter, Held at College of Education (technical),Asaba.

[10] Johnson, B.F and Mellor, J.W. (1961), The Role of Agriculture in Economic DevelopmentA.E.R., September.

[11] Izekor, O.B and Alufohai, G.O. (2010). Assessment of Cooperative Societies Effectiveness in Agricultural Credit Delivery in IkpobaOkha Local Government Area, Edo State, Nigeria; African Journal of General Agriculture, 6 (3): 139-142.

[12] Nwaru,J.C.

(2004).Ruralcreditmarketsandresourceuseinarablecrop productioninImoStateofNigeria.Ph.D.Dissertation, MichaelOkpara University of Agriculture, Umudike, Nigeria.

[13] Nwaru, J.C. (2011). Determinants of Informal Credit Demand and Supply among Food Crop Farmers in Akwa Ibom State, Nigeria, Journal of Rural and Community Development; 6(1): 129-139.

[14] National Population Commission[NPC] (2006). National Population Census, Nigeria.

\section{[15] Delta State Household Survey 2006}

[16] http://www.peoplesdaily-online.com/news/agriculture/34610 -delta-disburses-n1bn-agric-loan-to-934-farmers-cooperative s retrieved on $20 / 04 / 2012$. 